\title{
Bicycle helmet use among schoolchildren-the influence of parental involvement and children's attitudes
}

P Berg, R Westerling

\begin{abstract}
Objective-To study attitudes towards and use of bicycle helmets among schoolchildren; to determine whether these attitudes are associated with the involvement of parents and school in bike safety.

Settings-Nine intermediate level schools and five upper level schools in two Swedish municipalities.

Method-A survey with 1485 participants aimed at pupils aged 12-15 years conducted during late spring 1997. Associations between parent and school involvement and children's attitudes and helmet use were studied using LisRel analyses.

Result-At some point during their school years, a majority of the children stopped wearing bicycle helmets. Of 12-13 year olds, $80 \%$ said that they had used helmets when they were younger but at the time of the study, only 3\% aged 14-15 years used helmets. Use decreased significantly during school years $(p<0.001)$. The majority stated they quit using helmets because they were ugly, silly, uncomfortable, or inconvenient. There was a strong association between parental involvement, children's attitudes, and helmet use. However, parent involvement decreased as the children grew older.

Conclusion-To increase the voluntary use of bicycle helmets among schoolchildren their attitudes must be influenced. An intervention aimed at both parents and children may be required.

(Injury Prevention 2001;7:218-222)
\end{abstract}

Keywords: bicycle helmet use; parental involvement; children's attitudes; safety promotion

Head injuries resulting from bicycle related accidents are a global problem. Each year in the United States, 300000 children are treated in emergency departments for bicycle injuries; one third of which involve the head. ${ }^{1}$ In Sweden it is estimated that $35000-50000$ cyclists are injured and need medical care ${ }^{2}$ and 5000 cyclists are hospitalised each year. ${ }^{3}$

A Swedish study shows that one third of bicycle casualties involve schoolchildren, ${ }^{4}$ and in Australia, the proportion is two thirds. ${ }^{5}$ Almost $25 \%$ of all brain injuries in children are bicycle related ${ }^{6}$ and two thirds of bicycle injuries involve the head. ${ }^{8}$
A bicycle helmet reduces the risk of head injury by between 60 to $90 \% .^{910}$ Making people wear helmets is cost effective. ${ }^{2}{ }^{11-15}$

In 1991 the Swedish Helmet Initiative Group was formed by the World Health Organization Collaborating Centre on Community Safety Promotion at the Karolinska Institutet. Since then campaigns aimed at influencing the public have been common, along with some campaigns aimed at more specific groups. ${ }^{8}$ There are, however, no national helmet regulations in Sweden. Observational studies of helmet use in Sweden have been carried out annually by the Swedish National Road and Transport Research Institute since 1988. These reveal a change in helmet use among $12-15$ year olds. ${ }^{16}$

The objective of this study is to survey the use of, and attitudes towards bicycle helmets in this age group. Specifically, we wish to determine whether these attitudes and behaviours are associated with the involvement of parents and school. This will help determine if there is a need for an intervention to increase voluntary helmet use.

\section{Subjects and methods}

The municipalities of Bålsta and Enköping are situated in Uppsala County, $50 \mathrm{~km}$ and $80 \mathrm{~km}$ respectively north east of Stockholm. Bålsta has 17000 inhabitants and Enköping 36000 inhabitants, with $24 \%$ and $22 \%$ between $0-15$ years, respectively. Swedish grade schools are organised on three levels: junior 8-10 years; intermediate 11-13 years; upper 14-16 years.

A survey involving all pupils aged $12-15$ was conducted in spring 1997 involving all 14 schools in the two municipalities - a total of 2076 pupils. Altogether 1673 participated and 1485 answered the questionnaire. Questions included: use of bicycle helmets, attitudes towards helmets, the involvement of parents and school, and intended future use of helmet. The frequencies of use and attitudes were analysed using SAS. ${ }^{17}$ Differences were tested with $\chi^{2}$ analyses.

To analyse the association between the involvement of parents and school and helmet use, we used LisRel path analysis ${ }^{18}$ - a multivariate approach where the relative influence of parents and schools was examined. The method made it possible to determine the extent to which parents' and schools' involvement had a direct influence on helmet use or whether the influence was indirect, operating by their influence on attitudes. 


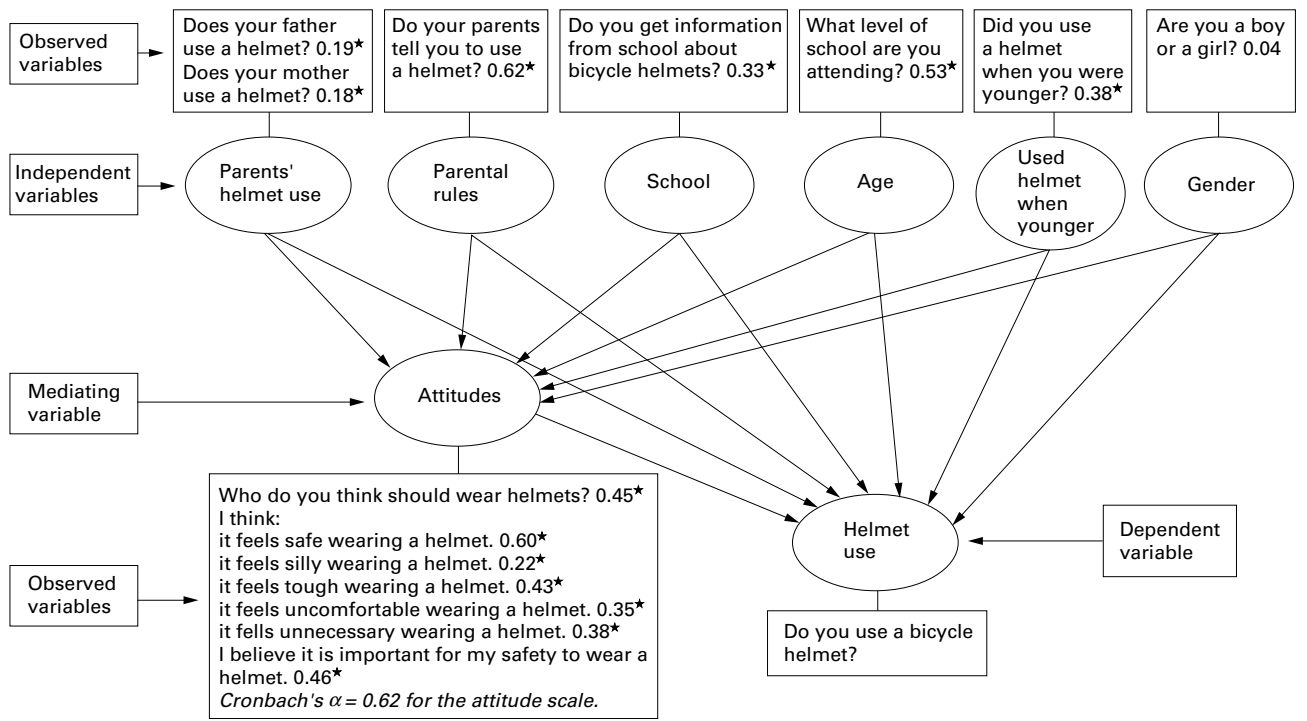

Figure 1 Postulated model where the independent variables'influence on the dependent variable can either be direct or indirect via the mediating variable. Observed variables (that is, questions asked in the survey) with correlation to helmet use $\left({ }^{*} p<0.05\right)$.

Parent and school involvement, the influence of age, sex, and earlier helmet use were included as independent variables in our model. Attitudes served as a mediating variable, and helmet use as a dependent variable.

The polychoric correlations between the variables included in the model with helmet use are presented in fig 1 . Missing values were treated using pairwise deletion. A maximum likelihood solution of the model was calculated.. LisRel estimates are estimates of the effect (the strength) that an independent variable has on a dependent variable, keeping all other independent variables at fixed values. The estimates can only be compared with each other and only within the same model.

\section{Results}

Most children reported having worn helmets when they were younger $(80 \%$ at the intermediate level and $60 \%$ at the upper level). At the time of the study, however, only $27 \%$ of 12 year olds wore helmets and by 15 years, the figure was $1 \%$ (fig 2 ). A majority ceased wearing helmets after they started attending school. Around $20 \%$ stopped at the junior level, but $62 \%$ stopped at the intermediate level. We did not find any significant difference in helmet use between boys and girls, but boys stopped using helmets at earlier ages than did the girls.

\section{ATTITUDES}

Children at all ages gave similar reasons for why they stopping wearing helmets. A majority $(60 \%)$ reported that they quit because they thought wearing helmet was ugly, silly, uncomfortable, or inconvenient (table 1).

There was a discrepancy between what the children believed to be the reasons for stopping and reasons for actually stopping. For example, $75 \%$ were of the opinion that children stop because they are afraid of being teased. However, only $1 \%-3 \%$ claimed that they did so for this reason. Similarly, $80 \%$ believed others

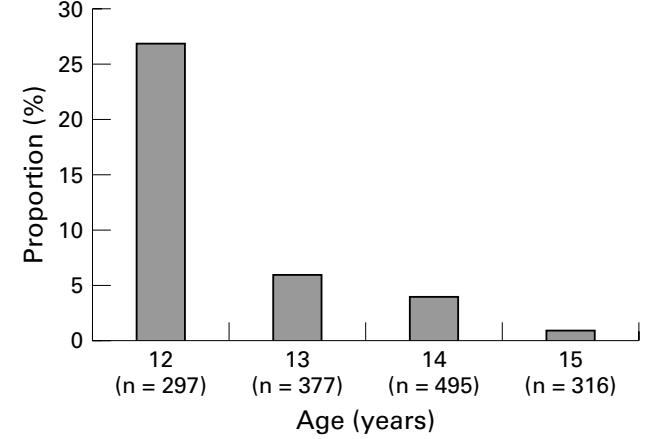

Figure 2 Proportion of schoolchildren aged 12-15 years who use a bicycle helmet, by age $(p<0.001)$.

quit because their friends did so but only $10 \%$ gave this as the reason they stopped.

A clear majority stated it is important to wear a helmet for safety (table 2) and $99 \%$ of those who still used helmets at the intermediate level believed that it is "very" or "rather important" for their safety. Even among those who did not use helmets, as many as $75 \%$ believed them to be very or rather important safety measures. Children at the upper level had similar attitudes (respectively $87 \%$ and $67 \%$ ).

There were significant differences, however, between boys and girls: more girls than boys believed helmets were important to safety and girls reported that helmets were more uncomfortable and silly than did boys.

Most helmets users (80\%) thought everyone should wear one when cycling. Even among those who did not wear helmets, one third thought everyone should use helmets.

Parental rules were considered important by $80 \%$ of the children at the intermediate and $63 \%$ at the upper level. In general most children $(55 \%-76 \%)$ judged it important for helmet use that parents, friends, and older pupils use helmets and that the school disseminates related information.

A minority at the intermediate level stated they intended to wear helmets when they 
Table 1 The proportion (\%) of the children that stopped using helmet by their stated reason to stop and by level of school

\begin{tabular}{lll}
\hline & Level of school \\
\cline { 2 - 3 } Stated reason & $\begin{array}{l}\text { Intermediate level } \\
(n=408)\end{array}$ & $\begin{array}{l}\text { Upper level } \\
(n=631)\end{array}$ \\
\hline It is ugly/silly & 35 & 37 \\
It is uncomfortable & 15 & 14 \\
It feels unnecessary & 10 & 12 \\
It is inconvenient & 13 & 12 \\
My friends have stopped & 10 & 10 \\
Need a new helmet (old one are broken or too small) & 9 & 7 \\
My parents have stopped telling me & 2 & 3 \\
Other reasons & 2 & 1 \\
I have been harassed & 3 & 1 \\
I wanted to be tough & 1 & \\
\hline
\end{tabular}

Table 2 The proportion (\%) of all the children who agree with the following attitude statements

\begin{tabular}{ll}
\hline Agree with the statement & $\begin{array}{l}\text { Children aged } \\
12-15 \text { years }\end{array}$ \\
\hline Only children should use helmet & 52 \\
Everyone should use helmet & 39 \\
It feels safe wearing helmet & 25 \\
It feels silly wearing helmet & 57 \\
It feels tough wearing helmet & 4 \\
It feels uncomfortable wearing helmet & 55 \\
It feels unnecessary wearing helmet & 21 \\
It is important for my security wearing helmet & 76 \\
\hline
\end{tabular}

reached the upper level, and a little less than two thirds declared that they would not do so. Of those wearing helmets, $40 \%$ said that they would continue doing so and another $50 \%$ said that they might continue to do so. Most of those who did not use helmets said they would continue not to; $20 \%$ said, though, that they might start using helmets again. Somewhat more of those who used helmets when younger intend to wear them at the upper level compared with those who did not use them when younger. There was no significant gender difference.

A minority favoured compulsory helmet legislation, and this decreased with age. About half of the children age 12 and most of the children age of 15 opposed such legislation.

IMPORTANCE OF PARENTS AND SCHOOLS

The involvement of adults seems to decrease as the children get older. The children reported a low helmet use among their parents $(1 \%-2 \%)$. About half had parents who stopped telling them to wear a helmet. Slightly more than one third at the intermediate level and $10 \%$ at the upper level declared that their parents had rules about bicycling with helmets. Importantly, most who use helmets $(84 \%)$ also had parents that still tell them to do so. Among the children at the intermediate level who had parents who set rules, one third used helmets; at

Table 3 Lisrel estimates showing the effect (the strength) that the independent variables and the mediating variable "attitudes" have on the dependent variable "helmet use"; values are estimate (SD)

\begin{tabular}{lccc}
\hline & Indirect effect & Direct effect & \multicolumn{1}{c}{ Total effects } \\
\hline Parents' use & $-0.01(0.01)$ & $0.23(0.02)^{\star}$ & $0.22(0.02)^{\star}$ \\
Parental rules & $0.14(0.01)^{\star}$ & $0.34(0.02)^{\star}$ & $0.48(0.02)^{\star}$ \\
School & $0.01(0.01)$ & $-0.08(0.02)^{\star}$ & $-0.07(0.02)^{\star}$ \\
Age & $0.03(0.01)^{\star}$ & $0.39(0.02)^{\star}$ & $0.42(0.02)^{\star}$ \\
Used when younger & $0.06(0.01)^{\star}$ & $-0.11(0.02)^{\star}$ & $-0.05(0.02)^{\star}$ \\
Gender & $-0.06(0.01)^{\star}$ & $0.08(0.02)^{\star}$ & $0.02(0.02)$ \\
Attitudes & - & $0.33(0.03)^{\star}$ & $0.33(0.03)^{\star}$ \\
\hline
\end{tabular}

${ }^{\star}$ Parameter estimates are significant $(\mathrm{p}<0.05)$.

\section{Key points}

- A majority of the children ceased wearing bicycle helmets after they started attending school.

- The greatest influence on bicycle helmet use was from parental rules, age, and attitudes of the children.

- Parental rules, meaning that parents tell their children to wear helmets when cycling, were considered as important by $80 \%$ of the children at the intermediate and $63 \%$ at the upper level.

- However, the involvement of the parents seems to decrease considerable as the children grow older.

- To increase the use of bicycle helmets among schoolchildren on a voluntary basis, it is necessary that their attitudes are influenced and that parental involvement is emphasised.

the upper level, the proportion was one fifth. Among those with parents without rules, almost none of the children used helmets.

The involvement of the school seemed to decrease with age as well. Among both boys and girls of all ages, $10 \%$ said that they never received any information from their schools at the intermediate level. Information about helmets from schools fell substantially once the children reached the upper level. As many as $80 \%$ at the upper level said that they had never received any bicycle helmet information while attending school at that level.

\section{LISREL ANALYSES}

The greatest influence on bicycle helmet use was from parental rules, age, and attitudes of the children (fig 1, table 3). Parents' use of helmets also influenced the children's use significantly. Parental involvement mainly had a direct effect on helmet use. This was also true for the age of the children. Parental rules, however, also had an indirect effect by influencing the child's attitudes.

\section{Discussion}

Of children aged $12-13$ years, $80 \%$ reported that they had used bicycle helmets when younger. When this study was conducted, only $1 \%$ of the children aged 15 used helmets. A majority had stopped wearing helmets during their school years.

Several international ${ }^{11}{ }^{19-21}$ and national ${ }^{16}$ studies found higher helmet use among both older children and adults than what the results from this study show. Most likely, the difference in some cases can be explained by the fact that most studies use a wider age interval that includes younger children, thus producing the impression of greater use.

Most reported that they quit using their helmet because it was, or was supposed to be, ugly, silly, uncomfortable, and inconvenient. A majority was afraid of being teased, but only a few per cent claimed to have been teased. Thus, it is of great importance to inform 
children that the risk of being harassed is not as high as they appear to believe.

An important base for understanding helmet habits among schoolchildren would be a better understanding for how negative attitudes arise and how to influence such attitudes. The behavioural and psychological characteristics of adolescents may partly explain this. ${ }^{22}$ This will be of importance when designing future interventions along with socioeconomic and psychosocial factors. ${ }^{19} 20$ 23-31

Parental and school involvement seems to decrease as the children grow older. Nearly half of the parents had stopped telling their children to wear bicycle helmets by the time the child was between 12 and 15 years. Despite very low helmet use among parents, there is a positive effect on use among children whose parents use helmets themselves. The influence from parents is obvious, and the school seems to be an under-utilised resource.

Even among those who do not use helmets, most children believed that helmets contribute to safety. Many also believed that everyone should wear a bicycle helmet when cycling. However, the study discovered a determined resistance against a compulsory helmet law. The strength of this attitude may help explain why international studies reveal only limited increases in helmet use among teenagers despite the passage of such laws. ${ }^{30}$

The claim by one third of the pupils at the intermediate level that they might use helmets at the upper level indicates that there is a considerable potential for increasing use among older children.

The pupils answered the questionnaire during school hours under the supervision of their teachers. This set an atmosphere of order and seriousness and probably positively affected the response rate.

However, one should be aware of the limitations due to the fact that the results are based on pupils' perceptions of the extent to which adults convey information and use helmets themselves. It might have been easier for children who use helmets to be aware of their parents' involvement. Yet in this study we do not have information about the parents' view of their use, but this should be an important issue for further studies. There may also be recall bias concerning the data on previous helmet use. Therefore, one should be cautious when drawing conclusions about the correlations. Nevertheless, there seems to be a strong association between the children's belief about their parents' involvement and their own use of helmets.

The LisRel analysis used in this study provides in-depth understanding of the mechanisms that influence the use of helmets. Our LisRel model helped elucidate the importance of the part played by parents and the limited contribution of the school. The methodological point to be made here is that if the children were asked directly, their answers indicated that attitudes were the main reason for not using helmets. However, the LisRel analysis showed an obvious connection with parental involvement. This involvement turned out to have connections both to the children's attitudes and to their helmet use. The influence of parental rules appeared to have the strongest effect on use.

\section{Implications for prevention}

International interventions to increase bicycle helmet use among schoolchildren, mainly from the US, Canada, and Australia, have shown that community-wide campaigns aimed at schoolchildren have a positive effect on the use of and attitudes towards helmets. ${ }^{10} 31-38$ An important task would be to motivate parents to encourage their children to use helmets, ${ }^{18} 19233039$ as shown by this study. Activities aimed at both the children and their parents are likely to yield the best result. ${ }^{31}$

It is important that interventions continue over a long period of time. ${ }^{36}$ Otherwise, one runs the risk that the changes in attitudes will not endure. ${ }^{28} 294041$

By merging experiences from earlier interventions together with the results from this study, we believe it may be possible to achieve a lasting increase in helmet use among schoolchildren based on voluntary decisions.

We thank Uppsala County Council for their support and financing and Stiftelsen Länsförsäkringsbolagens Forskningsfond (a Swedish insurance company research foundation) for support of the LisRel analyses. We also thank Associate Professor Dag Sörbom for statistical advice.

1 Data from the National Electronic Injury Surveillance System. Bicycle related injuries. FAMA 1987;257:3334-8.

2 Björnstig U, Andersson P. Hjälmlag - effektivt sätt att minska skador? [Bicycle helmet law-an effective way to decrease injuries? In Swedish]. Läkartidningen 1995: 7.

3 Center for Epidemiology at the Swedish National Board of Health and Welfare. The hospital discharge register. Statistics 1987-1996.

4 Schelp L, Ekman R. Road traffic accidents in a Swedish municipality. Public Health 1990;104:55-64.

5 McDermott FT. Why pedal cyclists should wear safety helmets. Aust Fam Physician 1984;13:284-5.

6 Fife D, Davis J, Tate L, et al. Fatal injuries to bicyclists; the experience of Dade County, Florida. $\mathcal{F}$ Trauma 1983;23: experien $745-55$.

7 O'Rourke NA, Costello F, Yelland JDN, et al. Head injuries to children riding bicycles. Med F Aust 1987;146:619-621.

8 Ekman R, Schelp L, Welander G, et al. Can a combination of local, regional and national information substantially increase bicycle-helmet wearing and reduce injuries? Experiences from Sweden. Accid Anal Prev 1997;29:321-8.

9 Thompson RS, Rivara FP, Thompson DC. A case-control study of the effectivnes of bicycle safety helmets. $N$ Engl $\mathcal{F}$ Med 1989;320:1361-7.

10 Thomas S, Acton C, Nixon J, et al. Effectiveness of bicycle helmets in preventing head injury in children: case-control study. BMf 1994;308:173-6.

11 Haziandreu EJ, Sacks JJ, Brown R, et al. The cost effectiveness of three programs to increase use of bicycle helmets among children. Public Health Rep 1995;110:251-9.

12 The Swedish Helmet Initiative Group, L Svanström. Letter to the Minister Ines Uusmann of the Swedish Department for Transport and Communication. March 1996.

13 Wärme P-E, Bergström R, Persson L. Neurological intensive care improves outcome after severe head injury. intensive care improves outcome after se

14 Schalén W, Nordström G, Nordström C-H. Economic aspects of capacity for work after severe traumatic brain esions. Brain Inj 1994;81:37-47.

15 Healy M, Maisley G. The impact of helmet wearing legislation and promotion on bicyclists in Western Australia. Perth: WA Police Department, August 1992.

16 Swedish Road and Transport Research Institute. Bulletin 844, 1998.

17 SAS Institute Inc. Software release 6.12. Cary, NC: SAS Institute Inc.

18 Jöreskog KG, Sörbom D. LISREL 8-users' reference guide. Chicago: Scientific Software International, 1993.

19 Caplow MP, Runyan CW. Parental responses to a child bicycle helmet ordinance. Am F Prev Med 1995;11:371-4.

20 Miller PA, Binns HJ, Christoffel KK. Children's bicycle helmet attitudes and use. Association with parental rules. The Pediatric Practice Research Group. Arch Pediatr Adolesc Med 1996;150:1259-64.

21 Sacks JJ, Kresnow M, Houston B, et al. Bicycle helmet use among American children, 1994. Inj Prev 1996;2:258-62. 
22 Berg-Kelly K. Normative developmental behaviour with implications for health and health promotion among adolescents-a Swedish cross-sectional survey. Acta Paedi-

$3 \mathrm{Hu}$ X, Wesson DE, Par ownership, use and related factors among school-children in metropolitan Toronto. Can F Public Health 1994;85:1214.

24 Puczynski M, Marshall DA. Helmets! All the pros wear them. Am $\mathcal{F}$ Dis Child 1992;146:1465-7.

25 Di Guiseppi CG, Rivara FP, Koepsell TD. Attitudes toward bicycle helmet ownership and use by school-children. $A m \mathcal{F}$ Dis Child 1990;144:83-6.

26 Towner P, Marvel MK. A school-based intervention to increase the use of bicycle helmets. Fam Med 1992;24:1568.

27 Parkin PC, Spence LJ, Hu X, et al. Evaluation of a promotional strategy to increase bicycle helmet use by children. tional strategy to increase
Pediatrics 1993;91:772-7.

28 Gielen AC, Joffe A, Dannenberg AL, et al. Psychosocial factors associated with the use of bicycle helmets among chiltors associated with the use of bicycle helmets among children in counties with

29 Seijts GH, Kok G, Bouter LM, et al. Barriers to wearing bicycle safety helmets in the Netherlands. Arch Pediatr Adolesc Med 1995;149:174-80.

30 Finch CF. Teenagers' attitudes towards bicycle helmets three years after the introduction of mandatory wearing. In Prev 1996;2:126-30.

31 Pendergrast RA, Ashworst CS, DuRant RH, et al. Correlates of children's bicycle helmet use and short-term failure of school-level interventions. Pediatrics 1992;90:354-8.
32 Rivara FP, Thompson DC, Thompson RS, et al. The Seattle children's bicycle helmet campaign: changes in helmet 33 Morris BA, Trimble NE, Fendley SJ. Increasing bicycle helmet use in the community. Measuring response to a widescale, 2-year effort. Can Fam Physician 1994;40:1126-31.

34 DiGuiseppi CG, Rivara FP, Koepsell TD, et al. Bicycle helmet use by children. Evaluation of a community-wide helmet campaign. $7 A M A$ 1989;262:2256-61.

35 Rourke LL. Bicycle helmet use among schoolchildren. Impact of a community education program and a cycling fatality. Can Fam Physician 1994;40:1116-24.

36 Farley C, Otis J, Benoit M. Evaluation of a four-year bicycle helmet promotion campaign in Quebec aimed at children ages 8 to 12: impact on attitudes, norms and behaviours. Can $\mathcal{F}$ Public Health 1997;88:62-6.

37 Dowswell T, Towner EM, Simpson G, et al. Preventing childhood unintentional injuries-what works? A literature review. Inj Prev 1996;2:140-9.

38 Bergman AB, Rivara FP, Richards DD, et al. The Seattle children's bicycle helmet campaign. Am $\mathcal{f}$ Dis Child 1990;144:727-31.

39 Otis J, Lesage D, Godin G, et al. Predicting and reinforcing children's intentions to wear protective helmets while bicycling. Public Health Rep 1992;107:283-9.

40 Logan P, Leadbetter S, Gibson RE, et al. Evaluation of a bicycle helmet giveaway program-Texas, 1995. Pediatrics 1998;101 (4 pt 1):578-82.

41 Ressler WH, Toledo E. Kasdah B'Rosh Tov: a description and evaluation of the Israeli bicycle helmet campaign. Health Educ Behav 1998;25:354-70.

\section{Despite critics, New York City moves closer to requiring helmets for scooter riders}

Less then a month after legislators introduced a bill taking aim at drivers who use cell phones, the City Council set its sights on the juvenile scooter set. This time, it is considering branding helmetless scooter tykes as outlaws. Some of the critics said that a helmet would take all of the fun out of the popular toys, which are sold from Main Street to Madison Avenue, relegating them to the back of the closet. Describing scooters as a "simple pleasure of childhood", Martha Rowen, a member of Right of Way, a pedestrian advocacy group, said, "The exercise children get with a scooter develops strength, coordination and a whole range of motor abilities, not to mention helping prevent obesity, a huge and growing problem for both children and adults in our society". She also said that adults would resist carrying children's helmets to playgrounds or parks along with the scooters and other gear that are already needed for such excursions. Others said that helmets were not needed because riding scooters was no more dangerous than playing on swing sets or playing touch football.

Even the city's Police Department and Department of Health had parts of the bill softened from its original version before the council's committee on health passed it 7 to 0 .

But the Democratic chairman of the Council's committee on health, said data compiled by the federal government showing a rash of scooter related injuries, including 8600 mishaps in September, demonstrated that helmets were necessary. He said no data were available for scooter related injuries in New York City. A 6 year old boy was killed in Elizabeth, NJ, in September when he rode his scooter into traffic, although the authorities said later that a helmet would not have saved him.

Once signed by Mayor Rudolph W Giuliani, who has already endorsed it, the bill would become law in 60 days. Violators could be fined $\$ 50$. One amendment to the original bill, which was added to satisfy the police, stipulates that summonses will not be issued directly to children, but only to parents or guardians who are present when scooters are being used without helmets. Another amendment, which came in response to objections from the Department of Health, removed a requirement that emergency room personnel at public hospitals inform the police when children are treated for scooter related head injuries. Instead, the bill passed yesterday calls on city health officials to prepare and distribute educational material on the hazards of scooters (New York Times, January 2001). 